51. Gearing M, Schneider JA, Rebeck GW, Hyman BT, Mirra SS. Alzheimer's disease with and without coexisting Parkinson's disease changes: apolipoprotein E genotype and neuropathologic correlates. Neurology 1995;45:1985-1990.

52. Martinoli MG, Trojanowski JQ, Schmidt ML, et al. Association of apolipoprotein epsilon 4 allele and neuropathologic findings in patients with dementia. Acta Neuropathol 1995; 90:239-243.

53. Helisalmi S, Linnaranta K, Lehtovirta M, et al. Apolipoprotein $\mathrm{E}$ polymorphism in patients with different neurodegenerative disorders. Neurosci Lett 1996;205:61-64.

54. Arai H, Higuchi S, Sasaki H. Apolipoprotein E genotyping and cerebrospinal fluid tau protein: implications for the clinical diagnosis of Alzheimer's disease. Gerontology 1997;43(suppl 1):2-10

55. Whitehead AS, Bertrandy S, Finnan F, Butler A, Smith GD, Ben-Shlomo Y. Frequency of the apolipoprotein E epsilon 4 allele in a case-control study of early onset Parkinson's disease. J Neurol Neurosurg Psychiatry 1996;61:347-351.

56. Inzelberg R, Chapman J, Treves TA, et al. Apolipoprotein E4 in Parkinson disease and dementia: new data and metaanalysis of published studies. Alzheimers Dis 1998;12: $45-48$.

57. Oliveri RL, Nicoletti G, Cittadella R, et al. Apolipoprotein E polymorphisms and Parkinson's disease. Neurosci Lett 1999; 277:83-86.

58. Harhangi BS, de Rijk MC, van Duijn CM, Van Broeckhoven C, Hofman A, Breteler MM. APOE and the risk of PD with or without dementia in a population-based study. Neurology 2000;54:1272-1276.

59. Kehoe P, Krawczak M, Harper PS, Owen MJ, Jones AL. Age of onset in Huntington disease: sex specific influence of apolipoprotein E genotype and normal CAG repeat length. J Med Genet 1999;36:108-111.

\title{
Neuro/mages
}
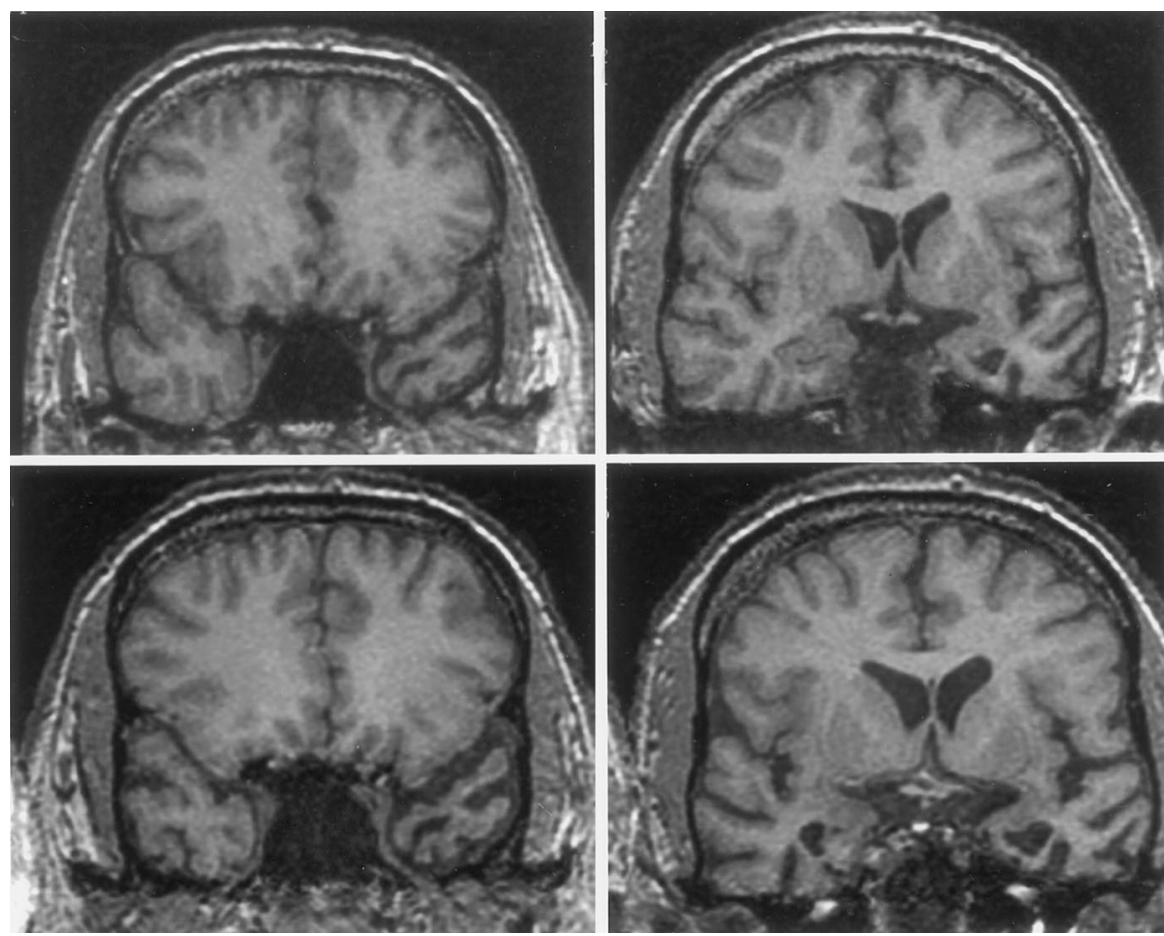

Figure. Representative T1-weighted coronal MRI at ages 53 (top row) and 55 (bottom row) are shown. Note progressive atrophy of the left amygdala and temporal cortex, and although a definitive causal relationship cannot be made, the right amygdala and temporal cortex atrophy has evolved in concert with the patient's polka music obsession.

\section{Polka music and semantic dementia}

Bradley F. Boeve, $M D$, and Yonas E. Geda, $M D$, Rochester, MN

A man exhibited typical features of semantic dementia, ${ }^{1}$ with onset at age 52. At age 55, he became infatuated with polka music. He would sit in his car in the garage and listen to polka on the radio or on cassettes, often for as long as 12 to 18 hours. Whereas some may argue that enjoying polka music is in itself pathologic, we view this patient's new appreciation of polka similar to that recently described with pop music in two patients with frontotemporal dementia. ${ }^{2}$ Thus, heterogeneity in musical taste is yet one more dimension bridging semantic dementia and frontotemporal dementia.

1. Neary D, Snowden J, Gustafson L, et al. Frontotemporal lobar degeneration: a consensus on clinical diagnostic criteria. Neurology 1998;51: 1546-1554.

2. Geroldi C, Metitieri T, Binetti G, Zanetti O, Trabucchi M, Frisoni G. Pop music and frontotemporal dementia. Neurology 2000;55:1935-1936. 


\title{
Neurology
}

\author{
Polka music and semantic dementia \\ Bradley F. Boeve and Yonas E. Geda \\ Neurology 2001;57;1485 \\ DOI 10.1212/WNL.57.8.1485
}

This information is current as of October 23, 2001

\section{Updated Information \& Services}

\section{References}

Citations

Subspecialty Collections

Permissions \& Licensing

Reprints including high resolution figures, can be found at: http://n.neurology.org/content/57/8/1485.full

This article cites 2 articles, 2 of which you can access for free at: http://n.neurology.org/content/57/8/1485.full\#ref-list-1

This article has been cited by 1 HighWire-hosted articles: http://n.neurology.org/content/57/8/1485.full\#\#otherarticles

This article, along with others on similar topics, appears in the following collection(s): All Cognitive Disorders/Dementia http://n.neurology.org/cgi/collection/all_cognitive_disorders_dementi a

Information about reproducing this article in parts (figures,tables) or in its entirety can be found online at:

http://www.neurology.org/about/about_the_journal\#permissions

Information about ordering reprints can be found online:

http://n.neurology.org/subscribers/advertise

Neurology ${ }^{\circledR}$ is the official journal of the American Academy of Neurology. Published continuously since 1951, it is now a weekly with 48 issues per year. Copyright . All rights reserved. Print ISSN: 0028-3878.

Online ISSN: 1526-632X.

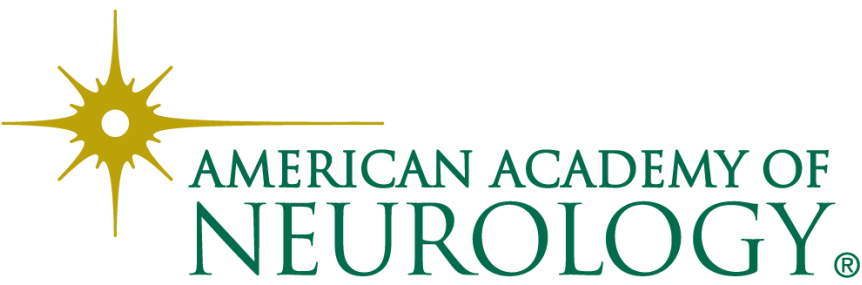

